\title{
The Theology of Spirituality: Its Growing Importance Amid the Transformations of the Modern World and the Church ${ }^{1}$
}

\author{
ADAM RYBICKI \\ The John Paul II Catholic University of Lublin \\ adam.rybicki@kul.pl, ORCID: 0000-0002-2417-6225
}

\begin{abstract}
This article raises issues surrounding the theology of spirituality as a relatively new theological focus. It argues that, faced with a changing world and numerous new (or perceived as new) phenomena, the theology of spirituality, as a scholarly area examining spiritual experience, is becoming a branch of theological research of increasing importance. The first part of this article focuses on the ever-growing areas of interest found within the theology of spirituality, a growth stemming from the core of the field itself (agere sequitur esse). The second part emphasizes the newer areas of interest within the theology of spirituality. These new horizons arise from the pluralism of theology itself and the criteria used in differentiating theological disciplines, such as ethno-geographic, doctrinal, and ascetic-practical concerns. In particular, amid a fast-changing world in which information and mutual contact have become incredibly accessible, the interpenetration of cultures and traditions can not only be of great value but also carry the dangers of a chaotic eclecticism. As this accessibility becomes ever easier and more pervasive, contemporary human beings can thus become confused, not only about their worldviews but also concerning their spiritual and religious beliefs. Thus, research into the theology of spirituality is becoming increasingly more important.
\end{abstract}

Keywords: spirituality, theology of spirituality, modern times

The 12th and 13th centuries witnessed the formation of scientific communities in which knowledge and its devotion united the social collectivity, creating a special civitas academica, which integrated various sciences, professor-masters and scholars (students), multilingual nationalities, and different social classes. This group as a whole comprised the universitas collegiorum et scientiarum, which was governed by its own separate regulations. It was a community of people dedicated to science. It was also an extraordinary scientific and cultural community. The universitas encompassed all fields, while theology was the queen of science.

With the passage of time, the universitas embraced increasingly more sciences and disciplines of knowledge. The university was then not only the supreme intellec-

1 The project is funded by the Minister of Science and Higher Education within the program under the name "Regional Initiative of Excellence" in 2019-2022, project number: 028/RID/2018/19, the amount of funding: 11742500 PLN 
tual, cultural, and legal institution but was also a spiritual and moral institution as well. ${ }^{2}$ This university community formed a social intelligentsia, interpreted life and the world, and thus the university played an important role in the creation of a new society in the medieval world. Unfortunately, after the Middle Ages there appeared a growing tendency to dehumanize science. The idea of the university carries universalism in itself, this means the university does not restrict itself to any monism, or reduce itself to solely a single culture or philosophy (like Marxism, liberalism, materialism, etc). ${ }^{3}$ It should be strongly emphasized that universities, which were founded in the High Middle Ages were born within religion, with this being their source of supreme personal and social wisdom. Theology, which was named the queen of the sciences in the Middle Ages, in the following centuries lost its position but did not cease to develop and expand the scope of its research. Thus, apart from the traditional areas of theological studies focusing on the Bible, patristics, dogma, and morality, a separate branch of academic theology was formulated whose research area concerns the manifold and broadly conceived spiritual experiences that can be seen in "ten thousand places."

Today, after years of science itself and the name thereof having evolved, this new branch of theology is called the theology of spirituality. This article presents the importance of this branch of science in the context of a changing world, new cultural phenomena, and the new spiritual currents that have emerged in the contemporary world. Ongoing transformations have opened up new fields of research for spirituality theologians and have raised questions that did not exist beforehand or did not demand a definite answer. ${ }^{5}$ Naturally, this text does not concern all of these fields or answer all of the new questions regarding the theology of spirituality. The aim of the presented content is rather to indicate an increasing number of research areas in the theology of spirituality and, taking into account its characteristics, to show its growing importance for the Church and her mission in the world.

Aumann, Zarys historii duchowości, 147.

Bartnik, Niszczenie humanistyki, 6-7.

This description refers to a fragment of the poem As Kingfishers Catch Fire, by G.M. Hopkins, which Peterson used to describe a diversity of spiritual experiences. For the full reference see Peterson, Christ Plays, 7.

5 Fiores, La "Nuova" Spiritualità, 28. 


\section{The Agere Sequitur Esse of the Theology of Spirituality}

Pina Bausch, a famous German dancer and contemporary dance choreographer, who strongly influenced the development of dance theatre as a genre, once said that she was not interested in how someone dances, but in which spirit moves the dancer. ${ }^{6}$ One can juxtapose this statement with St John's counsel: "Beloved, do not believe every spirit, but test the spirits to see whether they are of God; for many false prophets have gone out into the world" (1 John 4:1). Among all theological disciplines, this recommendation is most relevant to a relatively new theological discipline, developing in many parts of the world, whose most recent name is the theology of spirituality. As a science it truly "tests spirits, whether they are of God," and its role is to discern spiritual attitudes, practices, and phenomena. Although it appeared as an academic discipline as late as the beginning of the 20th century, the issues characteristic of today's theology of spirituality were already discussed in the theological reflection of ancient times, as exemplified by the writings of the Church Fathers.

In the sixteenth century, under the influence of humanistic trends, particular theological disciplines began to emerge. At that time, theology of spirituality was practiced as part of so-called mystical theology $\mathrm{y}^{7}$ or in combination with moral theology. Theology of spirituality became recognized as an academic discipline at the turn of the 20th century and was connected with the process of priestly formation. It was St. Pius $\mathrm{X}$ who introduced lectures on asceticism into the curriculum of seminary studies in his motu proprio Sacrorum Antistitum (1 September 1910). This decision was upheld and extended by later papal documents, with theology of spirituality being then included in university curriculums, first at the Pontifical University of St. Thomas in Rome (Angelicum) in 1917 and then at the Pontifical Georgian University in 1919.

The proclamation of St. John of the Cross as a Doctor of the Church by Pius XI in 1926 and the encyclical Deus Scientiarum Dominus (24 May 1931) became an incentive for further development of the theology of spirituality as an independent theological discipline, within which ascetic theology was recognized as a discipline of theology separate from moral and pastoral theology. Theology of spirituality's development was also influenced by two popes, Pius XI in the encyclical Ad Catholici Sacerdotii (20 December 1935) and Pius XII in the exhortation Menti Nostrae (23 September 1950) and in the encyclical Sedes Sapientiae (31 May 1956). In subsequent years, many scientific centers of the theology of spirituality were established including The Pontifical Theological Faculty Teresianum in Rome, founded in 1935 by the Polish Carmelite Father Anzelm Gądek ( $†$ 1969), and numerous theological

6 This paraphrase is based on a feature film of French-British-German production entitled Pina," by Wim Wenders, 2011.

7 Górski, “Teologia mistyczna," 217. 
faculties at various universities all over the world, with these faculties organizing institutes of spirituality or at least departments specializing in this field. ${ }^{8}$

Significantly, St. John Paul II spoke in his post-synodal exhortation Pastores Dabo Vobis upon the formation of priests in the modern world (25 March 1992): "In reflecting maturely upon the faith, theology moves in two directions. The first is that of the study of the Word of God: the word set down in holy writ, celebrated and lived in the living tradition of the Church, and authoritatively interpreted by the Church's Magisterium. Hence the importance of studying Sacred Scripture - 'which should be the soul, as it were, of all theology', the Fathers of the Church, the liturgy, the history of the Church and the teachings of the Magisterium. The second direction is that of the human person, who converses with God: the person who is called "to believe," "to live," "to communicate" to others the Christian faith and ethos. Hence, this direction includes the study of dogmatic theology, moral theology, the theology of spirituality, canon law and pastoral theology." This 'second direction' is growing in importance because man, as the subject of spiritual life, undergoes many internal and external changes and is subject to influence from a dynamically changing world. Hence the emerging postulate to incorporate the theology of spirituality into ever-new areas of research, into previously unknown problems, and to address the resulting challenges.

Observing the dynamic development of the theology of spirituality as a theological field as well as a new phenomenon of the spiritual nature of the Church and world, one may sometimes have the impression that academic theology of spirituality distances itself from the spiritual life of the faithful in the 21st century, is not interested in and does not examine what is currently happening in the Church, provokes questions, demands spiritual discernment, or even causes confusion. This is not consistent with the official pronouncements of the Church. Marek Chmielewski has analyzed the works of John Paul II's entire pontificate and concluded that the doctrine of this Polish pope showed a clear upward trend in the use of the term 'spirituality' in both encyclicals and exhortations. As early as in his third encyclical (Laborem Exercens), where the pope devoted a whole chapter to the spirituality of the work, we can observe an exponential increase in the interest the Holy Father had in spirituality in an ever wider range of meanings. The problem of spirituality was raised 100 times in John Paul II's exhortations, more than 30 times in his encyclicals, and countless times in his other documents - motu proprio, catecheses, and speeches. Additionally, this is proof of the growing importance of spirituality for the contemporary Church and can serve as encouragement for theologians to explore ever new areas of human life. ${ }^{10}$

Chmielewski, "Teologia duchowości," 880.

John Paul II, "Pastores Dabo Vobis," 54.

10 Chmielewski, "Duchowość według Jana Pawła II," 66. 
In today's world we can simultaneously observe a hunger for spirituality ${ }^{11}$ as well as an interest in various forms of spirituality that are alternative to Christianity. Due to civilizational changes and the increasing ease of contact and world-wide travel, it has become inevitable that, just as different cultural traditions and customs fuse together at times, new phenomena in spirituality have also appeared. Sometimes these phenomena, after being examined, prove to be neither new nor original, but rather appear as a novel combination of diverse elements, spiritual eclecticism, and as the widespread individualism found in the modern selection of spiritual and religious motifs.

In the encounter of Christian spirituality with other spiritual traditions, several variants of human reaction are possible. A world-renowned Polish reporter and traveller, Richard Kapuściński, in his lecture delivered on the occasion of being awarded the title of honorary doctor by the Jagiellonian University of Cracow, listed three reactions that people employ when any "other" appears in their path. The first reaction is conflict, war; the second one is separation, division and isolation; and the third reaction is interest, the permission to speak, to describe oneself, the possibility of getting to know each other, with this leading to eventual cooperation. The above statement can be applied to Christian spirituality, which in contact with other spiritual traditions can condemn and reject them, separate itself from them, or - and this seems to be the optimal solution - attempt to get to know them, for example by comparative studies. ${ }^{12}$ Therefore, the theology of spirituality, particularly in the age of increasingly intense interpersonal contacts, can help both parties of an encounter. On the one hand, the theology of spirituality can study the spirituality of non-Christian religious traditions, and on the other, it can present and popularize knowledge of Christian spirituality among people who are not familiar with it or rely on prejudiced and harmful stereotypes. In this case, knowledge, namely the theology of spirituality, can become a new kind of bridge between people, with this being invaluable in an atomized world. ${ }^{13}$

As mentioned above, the theology of spirituality has undergone a certain kind of evolution, as has its name. The most commonly used names for this field in recent decades include: ascetic theology, mystical theology, or in combination: ascetic-mystic theology, the theology of perfection, and the theology of inner life. Today, our domain of interest is almost exclusively referred to as the theology of spirituality or the theology of spiritual life. The term "mystical theology" was introduced in the early 6th century by Pseudo-Dionysius Areopagita and it functioned almost universally until the mid-17th century. It involved the totality of knowledge concerning spiritual life and the aspects of spiritual life including mystical experience. ${ }^{14}$ It is important to

\footnotetext{
John Paul II, “Novo Millenio Ineunte," 33.

Kapuściński, "Spotkanie z Innym", 65-76.

Rybicki, "Christian Spiritual Experience," 88-90.

Stępien, "Przedmowa," 61.
} 
clarify that because of the development of research within these areas, theology of spirituality and mystical theology are not synonymous anymore.

Mystical theology focuses primarily on mystical experience and not on widely understood spiritual experience. ${ }^{15}$ Here, ascetic-mystical theology indicates the ascetic character of spiritual life, man's systematic and long-term effort in establishing relations with God. But obviously the richness of spiritual experience goes far beyond the field of asceticism. Likewise, the very word "mysticism" (everything which is vague, mysterious, occult, irrational, prelogical, affective) is connected with extraordinary cognitive or psychosomatic phenomena, although its essence is testified to by completely different experiences. Within the theological sciences there was a division of mystical theology into so-called speculative and practical parts. Spirituality and reflection on spiritual and mystical life did not go hand in hand. It seems that in the current climate it would be advisable to postulate a combination of a deepened spiritual life and the studies thereof. The methodologists of the theology of spirituality emphasize its crucial feature concerning this point. The unifying perspective of the theology of spirituality concerns practice and theory, mysticism and asceticism, the Bible and liturgy, and psychology and dogmatics. Thus, what is the theology of spirituality in the face of its growing significance and increasingly multi-faceted role? Following the Thomistic principle of agere sequitur esse, it is possible to arrange individual, recently expanding research areas of the theology of spirituality according to the essence of this theology.

a) The theology of spirituality is a coordinating theology, the principle of understanding Revelation, requiring both biblical exegesis and a plethora of different schools of theology. Its growing role in the contemporary world must therefore take into account both the development of particular theological sciences as well as the practical and pastoral aspects of these transformations.

b) The theology of spirituality is an "existential pneumatology," which interprets reality in the light of the Holy Spirit and seeks to capture the presence and actions of the Holy Spirit in the lives of both individuals and the world. Hence, the theology of spirituality requires thorough study of the issue of "spiritual discernment," that is the search for evaluation criteria of what is inspired by the Holy Spirit in the present reality of the Church and the world and that which creates such appearances. ${ }^{16}$

c) The theology of spirituality is a theology of encountering, it examines the relational character of spiritual experience, and in this area gives particular value to the category of 'covenant'. It is precisely 'the spirituality of encounter'17 or 'the

15 Chmielewski, "Mistologia," 1275-1277.

16 It is worth noting at this point the development of reflection and literature concerning spiritual discernment. This has considerable significance in our world, which is confused in axiological, moral, spiritual, and other terms.

17 Ogorzałek, Duchowość spotkania, 365-370. 
culture of encounter' that is presented today as a remedy not only for the anonymity of contemporary culture, but also for mutual indifference, ignorance, or even the hostility of people and societies. Pope Francis is a fervent advocate of the 'culture of encounter,' and significant elaborations upon his teachings on this subject have already been published. ${ }^{18}$

d) The theology of spirituality is a theology of mystery and tends to interpret reality in the light of faith, gratitude, and trust.

e) The theology of spirituality is a spousal theology. It also examines the communion of man with God from the perspective of the body (mysticism and eros).

f) The theology of spirituality is a theology of consolation in this sense that it has a deeply therapeutic value that reveals the existential disintegration of contemporary man, facilitates his internal integration, protects him from the that results from such disintegration, and thus gives him hope by offering a new integration, a new synthesis of personality.

g) The theology of spirituality is a theology of wisdom because it is not only a conceptual perception, but relates to the sapiential dimension, showing man, who is now very confused, the paths of wisdom.

h) The theology of spirituality is a poetic theology. Theological reflection is revealed in language as exemplified by the poetry of the Fathers of the Church. Today's language as an instrument for the interpretation of spiritual works, especially in the field of Christian mysticism, is no longer sufficient. Therefore, there is a need to develop a hermeneutic of mystical works, with this lying in the sphere of the interests of the theology of spirituality. Research regarding language and interpretive keys can become the most important bridge between the contemporary reader of mystical works and ancient writings. ${ }^{19}$

i) The theology of spirituality is a personalistic and anthropological theology, ${ }^{20}$ which accentuates the human environment and promotes the world as a human world. ${ }^{21}$ Since spiritual development and spiritual formation have always been an area of interest for the theology of spirituality, today it seems only natural to benefit from the achievements of anthropology and psychology. ${ }^{22}$ Thus, in the context of spiritual development and formation, issues such as attitude, ${ }^{23}$ depression ${ }^{24}$ and defense mechanisms, ${ }^{25}$ and spiritual freedom ${ }^{26}$ need to be studied in

18 Tułowiecki, "Kultura spotkania," 375-400.

19 Bernard, Teologia spirituale, 232, Borriello, "Il linguaggio mistico," 153-176, Castro Martínez, "Il simbolismo mistico," 177-221.

20 Jastrzębski, Homo Theomorphicus, 25-27.

21 Guerra, Teologia espiritual, 408-401, Chmielewski, Metodologiczne problemy, 78-79.

22 Allen, Spiritual Theology, 31-46.

23 Niewiadomska, "Postawa," 684.

24 Catalan, Duchowość a psychologia; Catalan, Depresja a życie duchowe.

25 Paszkowska, Formacja eklezjalna, 180-191; Pacot, Droga wewnętrznego uzdrowienia, 33.

26 Ryan, Four Steps to Spiritual Freedom, s. 1-15. 
an interdisciplinary manner by contemporary spiritual theologians. W. Stinissen, A. Grün, J.H. Nouwen, D. Montgomery, and J.F. Catalan are among the authors who present various issues of Christian spirituality to a wide range of readers through their translated publications while also being in dialogue with psychology. Occasionally, allegations can be heard that the theology of spirituality has been psychologically seduced into reducing the phenomena of the spiritual order to psychology. However, other trends should also be observed in the contemporary world. During the period of post-conciliar turmoil, the theology of spiritual life was running parallel in at least two directions.

While a certain group of theologians, predominantly American, began to believe that spiritual processes are driven by psychological conditions, another group of theologians, Christian writers, who were then growing in strength, almost instinctively turned to mystagogy, which unveils God in contemplated love, while at the same time turning to asceticism, which creates the space for God in man, all the while giving psychology a supporting role. The Carmelite school of spirituality with its center in Rome, the Teresianum, is of particular interest here. The fruit of this school's turn towards mystagogy is the fact that modern Carmelite mystics (St. John of the Cross, St. Teresa of Avila, and St. Teresa of Lisieux) have been successively proclaimed as Doctors of the Church. ${ }^{27}$

\section{New Challenges Resulting from the Pluralism of Spirituality}

Despite the fact that there is one Christian spirituality, one can distinguish different types of spirituality and varied criteria of its division. In the modern world, every criterion opens up a whole range of problems that requires theological reflection. The following criteria are applied to spirituality in its diversity: ${ }^{28}$

a) Ethno-geographical criteria, such as the spirituality of the Christian East or West, and the spirituality of Africa and Europe. In the age of unlimited intercontinental travel, it is not only possible but also necessary that various elements should be brought into contact and dialogue. In Europe, for instance, evangelizers from Africa are sometimes criticized for introducing elements of African or Latin American spirituality into Europe as part of the so-called pentecostalization. ${ }^{29}$ These evangelizers are not typically understood in the same way as they are on their old continent.

b) Doctrinal criterion, which accentuates selected doctrinal content in spiritual experience, hence the reference to passion, Pentecostal, Marian, and Eucharistic spir-

27 Lubowicki, "Posłowie," 34.

28 The above division was suggested by Atanasio G. Matanić in his book La spiritualità, 46-49.

29 Kobyliński, "Etyczne aspekty," 112-113. 
ituality. It seems that contemporary Marian spirituality is becoming a special field of research for the theology of spirituality, be it because of the elements of popular piety connected with the traditions of a given community, be it due to the problems connected with so-called private Marian revelations which as an "experience of individual Christians and whole Christian communities" 30 are becoming an increasingly important source of spirituality or even faith and theology. The theology of spirituality also studies the broadly understood fruits of these revelations, not only as they concern the spiritual life of individual believers, but also in regards to the influence they have on a community of the Church, as in terms of the subsequent integration or disintegration of a community.

c) Ascetic and practical criterion, which emphasizes certain ascetic practices related to particular Christian virtues or groups of virtues such as: the spirituality of love and mercy, or communal, penitential, prayerful, and missionary spirituality. Speaking during a meeting at the John Paul II Catholic University of Lublin on the 27th of November, 2014, Ralph Martin pointed out with reference to the spirituality of mercy, which is spreading throughout the world through the Polish mystic St. Sister Faustina Kowalska, that it is increasingly evident that certain distortions of the idea of mercy arise from a too liberal interpretation of mercy. One of the ascetic and practical problems that has recently appeared in Poland is a new form of the sacrament of Penance which is known as the gateway confession. Its genesis is not quite clear. So far, no one has given a clearly formulated definition of what a 'gateway confession' is despite the practice's spread. The core of this form of confession consists in closing 'gates', hence the name 'gateway', which sin, personal or 'generational', has opened and thus enabled the presence of Satan, giving him a certain power over man. A characteristic feature of this 'gateway confession' is a highly developed, although limited to the first commandment of the Decalogue, examination of one's conscience and a prayer for deliverance which sometimes comes in the form of a solemn exorcism. As a result, in Poland a special theological commission examined this new phenomenon and formulated an opinion on the basis of which the President of the Episcopal Conference issued a ban on the practice of this form of confession. ${ }^{31}$

Other contemporary problems include those connected with the Pentecostal Movement include such as prayer in tongues or prayer for healing. Another contemporary problem area for spirituality theologians is the issue of Christian meditation. In some circles and spiritual literature there is a kind of fascination with Eastern meditation practices. This raises dogmatic and pastoral concerns. Nevertheless, the theology of spirituality and its study of the Church's prayer life as shaped over the centuries can give meaningful guidelines on the boundaries of interreligious dia-

John Paul II, Redemptoris Mater, 48.

31 The text of this ban, together with theological opinion, can be accessed on the homepage of the Polish Episcopal Conference (KEP). 
logue. Works by such authors as J. Main, T. Merton, B. Pennigton, L. Freemann and B. Griffiths are read all over the world and undoubtedly bring substantial spiritual benefits, but they also raise questions concerning the combination of Zen meditation and Christian meditation or the common relationships between Buddhist and Christian spirituality. Organized meetings, joint prayers, and scientific conferences undoubtedly contribute to the understanding of many ambiguities, ${ }^{32}$ but there is still a need for reliable theological and spiritual research in determining which forms of prayer constitute Christian prayer and which forms, as H.U. von Balthasar once said, are a "betrayal in the heart of the Church," or even spiritual "adultery."33 Admittedly, von Balthasar was right when he warned of this aforementioned type of spiritual syncretism, "The Church could not be wounded internally and mortally more than in the case of religious orders abandoning the prominent place of their Christian meditation, which they practice on behalf of the whole Church and the world, and withdrawing behind the curtain of non-Christian meditation. [...] It could not be called other than a betrayal of the crucified love of God [...], or adultery of much more terrible significance than that of the synagogue (cf. Ezekiel 16)." ${ }^{34}$

As shown recently by P. Piasecki, the influence of the Eastern concepts of meditation on Christian meditation is 'ambivalent'. Therefore, this ambivalence should be thoroughly and incessantly examined. ${ }^{35}$ In recent times, the theology of spirituality has also addressed the paramystic phenomena which are the focus of attention in literature, film, and the media generally. These phenomena are interpreted chaotically in the contemporary world, with this undoubtedly weakening their salvific significance. Theological and spiritual research, which must be undertaken continuously in cooperation with sciences such as psychology, neurotheology, and psychiatry, have an important role to play. ${ }^{36}$ On the one hand, this allows the theological environment, which is somewhat skeptical of this type of phenomena, to open up to problems concerning paramystic phenomena and, on the other hand, this helps maintain the necessary and proper rationalism and ecclesial context for all those who are overly enthusiastic when examining paramystic phenomena. The need for a balance between skepticism and openness is derived from the Bible, where both the Old and the New Testaments include paramystic phenomena of both cognitive and somatic orders. It seems that due to a certain dimension of contemporary culture, for example the cinema, people are increasingly interested in phenomena of demonic origin including oppression, possession, and exorcisms.

There is a great danger that the consciousness of the faithful and others will have a skewed and ultimately flawed interpretation of these phenomena, with this being

\footnotetext{
32 Bereza, „Sztuka codziennego życia," 73-91.

33 Balthasar, "Meditation als Verrat," 265.

34 Balthasar, "Meditation als Verrat," 265.

35 Piasecki, Medytacja chrześcijańska, 73-97.

36 Thompson, Journey Toward Wholeness, 2.
} 
the fruit of the 'licentia poetica' of the commercial imagination of filmmakers. Therefore, theologians of spirituality are conducting intensive research on the subject, the fruit of which is a rising number of publications on the subject. At this juncture, the pioneering and popularizing role of Gabriele Amorth, who contributed to a better, deeper, more theological, and simultaneously more common sense understanding of this complicated problem among Christians all over the world, should be noted. ${ }^{37}$ These are just a few examples of the growing number of phenomena, events, and currents in which the theology of spirituality, as a science with its own method and goal, is becoming increasingly more necessary. After all, the point of the theology of spirituality is not only to show anomalies or even spiritual dangers, but more so to present proper ways of spiritual development to the faithful. This is incredibly important because the Church is a living organism which is constantly undergoing transformations (semper reformanda). G. Weigel argues that under the influence of its surrounding culture, the contemporary Church is regrettably drifting towards a relaxed spirituality. G. Weigel decries this and states there is no true reform in the church if she becomes 'more relaxed' and accepts a 'dilution' of her rules and principles in terms of her doctrines, praxis, and spirituality. ${ }^{38}$ Therefore, another task of the theology of spirituality, alongside presenting the centuries-old spiritual traditions of the Church, is to indicate such forms and trends of reform which would have a prophetic value and lead to a truly spiritual development within the Church and not to pretense or degeneration.

d) Anthropological and Psychological Criterion, in referring to variables such as sex, age, temperament, and state of life, allows one to distinguish for example, the spirituality of women, men, children, adolescents, and adults. The spirituality of particular professions, priestly spirituality, and the spirituality of consecrated life should also be mentioned. The contemporary world is experiencing a wave of interdisciplinary debate on gender, the development of feminist ideology, and an increasingly acute crisis of masculinity and fatherhood. This makes it progressively indispensable to conduct in-depth studies concerning the spirituality of men and women and their mutual cooperation and complementarity. Recent years have seen a considerable flowering of reflection on this subject. We can even speak of some awakening of men and women who search for both their identity and a corresponding spirituality. ${ }^{39}$

\footnotetext{
37 Amorth, Wyznania egzorcysty; idem, Nowe wyzania egzorcysty; idem, Egzorcyści i psychiatrzy.

38 Weigel, Katolicyzm ewangeliczny, 145-146.

39 Arcimowicz, Obraz mężczyzny; Badinter, XY: tożsamość mężczyzny; Cordes, Zagubione ojcostwo; Eldredge, Dzikie serce; Grün, Walczyć i kochać; Hart, Meska depresja; Jan Paweł II, Mężczyzna i niewiasta stworzył ich; Congregation for the Doctrine of the Faith. Letter to the Bishops, 671; Berger - Wallis - Watson, Constructing Masculinity; Franklin, The Changing Definition of Masculinity; Guggenbühl, Men, Power, and Myths; Haddad, Men and Masculinities; Horrocks, Masculinity in Crisis; Mosse, The Image of Man; Pleck, The Myth of Masculinity; Rotundo, American Manhood; Stearns, Be a Man!; Hicks, The Quest of Self-Understanding, Rohr, "Masculine Spirituality."
} 
e) Historical and Chronological Criterion are some of the basic criterion of ordering various styles of spirituality according to their historical context. Therefore, we can speak of apostolic spirituality, early Church spirituality, Medieval spirituality, Baroque spirituality, contemporary spirituality, and post-conciliar spirituality. The problem that the theology of spirituality concerns itself with today is, among other things, the study and description of contemporary spirituality and its multiple determinants. Thus, theological and spiritual reflection encompass such issues as spirituality vs. the media revolution, ${ }^{40}$ the spirituality of new communities and associations, ecological spirituality, and contemporary charismatic movements. ${ }^{41}$

Modern times increasing pose threats that question an eschatological sense of history, the Parousia, and even the end of the world. Interestingly, these threats often arise in ecclesiastical circles, although they also emerge elsewhere. In some circles, this is the basis for a reflection which, having its origins in the biblical apocalypse, then drifts far from Christian spirituality. It must be admitted that in modern times the removal of God from the human horizon has made man, as A. Tornielli and S. Gaeta claim, "even more susceptible to the workings of myths, superstitions, many a time obvious nonsense, spread by the extraordinary and highly effective - but also dangerous - tool of communication, which is the Internet." 42 Therefore, this is another area of work for theologians of spirituality because, just as in the apostolic times when some Christians needed to be taught a proper approach to awaiting the Parousia and their enthusiasm needed to be grounded in the entirety of the biblical Revelation, it is now necessary to present the eschatological dimension of spiritual life in an appropriate way.

There are already organized groups of people all around the world who are preparing for a possible global cataclysm, epidemic, or some kind of global catastrophe. They are called 'preppers'. These preppers are training and preparing for the coming of the Apocalypse in various ways. They are collecting watches, water purification devices, and even multitasking tools. The philosophy of this movement, or subculture, is that in the event of a global disaster, the unprepared will perish, while the preppers will survive due to their accumulated provisions. They are doing their utmost to prepare for the 'apocalypse', and the movement is likely to gain more and more followers. Nevertheless, this movement is centered on a complete incomprehension of what the Apocalypse in the Bible is and what its corresponding spirituality is. ${ }^{43}$ Spiritual

40 The theology of spirituality, in addressing the problem of the presence of media in spirituality and the presence of spirituality in media, should find a wise (sapiencial) perspective that considers both the threats posed by the media (pornography, violence, mob mentalities, radicalism, addiction, the building of a consumer attitude, etc.) and the opportunities offered by the development of the media (communication, information, formation, etc.). See Meetschen, Cyfrowa duchowość, 27-59.

41 Holt, "Duchowość dwudziestego wieku," 355-365.

42 Tornielli - Gaeta, A.D. 2012, 8-9.

43 Sowers, Droga wojownika, 155-161. 
theology, in examining these "new" schools of spirituality, trends, and communities, and while also drawing on the 20th century experience of the Church, may in a sense predict which course a given phenomenon may take in the long term. Thus, for example, the experiences of the first charismatic communities or certain changes after the Second Vatican Council can be very instructive and helpful for planning the pastoral and catechetical activities in the future, and help people avoid obvious mistakes, which theologians have also observed in enthusiastic revival movements. ${ }^{44}$

f) The Criterion of Order Founders or of Schools of Spirituality that allows us to speak of Basilian spirituality, Augustinian spirituality, Benedictine spirituality, Dominican spirituality, Franciscan spirituality, Carmelite spirituality, Ignatian spirituality, and many other spiritualties. Consecrated life in a changing world is undoubtedly a point of interest for formators, but the dynamism of an ever changing world raises questions that are connected with contemporary trends and requires reliable research. Alongside traditional schools of spirituality, we are currently witnessing an explosion of new communities, associations, and spiritual trends within the Catholic Church. Emergent problems are not only of an organizational nature, or concern the Church's presence in the world, but are always primarily connected with spirituality. In fact, in contemporary times we are dealing with new forms of the Christian life, and today's challenge for the theology of spirituality is to study the heritage of such leaders as P.M. Delfieux, Brother Ephraim, and Chiara Lubich. Many others have also created communities and gave rise to spiritual trends that already have a breadth of influence, although they haven't yet been an object of scholarly reflection.

All the above mentioned issues indicate how serious the challenges are that face the relatively young theological discipline of the theology of spirituality. As a matter of fact, the contemporary world and new areas of human life, science, theology, and spiritual experience all contribute to presenting the theology of spirituality as a science with wide prospects and an ever broader range of interests. It remains to be seen if research in this field will remain solely scientific in nature. But through the promotion of knowledge, one will be able to observe the theology of spirituality's impact on spiritual life and the formation of the faithful. 


\section{Bibliography}

Allen, D., Spiritual Theology. The Theology of Yesterday for Spiritual Help Today (Lanham, MD et al:: Cowley 1997).

Amorth, G., Egzorcyści i psychiatrzy (trans. W. Wiśniowski) (Częstochowa: Edycja Świętego Pawła 1996).

Amorth, G., Nowe wyznania egzorcysty (trans. W. Zasiura) (Częstochowa: Edycja Świętego Pawła 1992).

Amorth, G., Wyznania egzorcysty (trans. F. Gołębiowski) (Częstochowa: Edycja Świętego Pawła 1999).

Arcimowicz, K., Obraz mężczyzny w polskich mediach (Gdańsk: Gdańskie Wydawnictwo Psychologiczne 2003).

Aumann, J., Zarys historii duchowości (trans. J. Machniak) (Kielce: Jedność 1993).

Badinter, E., XY: tożsamość mężczyzny (trans. G. Przewłocki) (Warszawa: W.A.B. 1993).

von Balthasar, H.U., "Meditation als Verrat," Geist und Leben 50/4 (1977) 260-268.

Bartnik, C., Hermeneutyka personalistyczna (Lublin: KUL 1994).

Bartnik, C., "Niszczenie humanistyki i teologii uniwersyteckiej," Nasz Dziennik 52 (2019) 6-7.

Bereza, J.M., Sztuka codziennego życia (Poznań: Zysk i S-ka 1993).

Berger, M. - Wallis, B. - Watson, S. (ed.), Constructing Masculinity (New York: Routledge 1995).

Bernard, Ch. A., Teologia spirituale (Roma: Paoline 1982).

Borriello, L., "Il linguaggio mistico," Mistica e mistica carmelitana (ed. L. Borriello) (Città del Vaticano: Libreria Editrice Vaticana 2002) 153-176.

Castro Martínez, G., "Il simbolismo mistico," Mistica e mistica carmelitana (ed. L. Borriello) (Città del Vaticano: Libreria Editrice Vaticana 2002) 177-221.

Catalan, J.-F., Depresja a życie duchowe (Kraków: eSPe 2002).

Catalan, J-F., Duchowość a psychologia (Kraków: eSPe 2007).

Chmielewski, M., Duchowość według Jana Pawła II. Studium na podstawie encyklik i adhortacji (Lublin: Polskie Stowarzyszenie Teologów Duchowości 2013).

Chmielewski, M., "Mistologia," Encyklopedia katolicka (ed. E. Ziemann) (Lublin: TN KUL 2008) XII, 1275-1277.

Chmielewski, M., Metodologiczne problemy posoborowej teologii duchowości katolickiej (Lublin: RW KUL 2001).

Chmielewski, M., “Teologia duchowości,” Leksykon duchowości katolickiej (ed. M. Chmielewski) (Lublin - Kraków: Wydawnictwo M 2002) 880-885.

Congregation for the Doctrine of the Faith, "Letter to the Bishops of the Catholic Church on the Collaboration of Men and Women in the Church and in the World," Acta Apostolicae Sedis 96 (2004) 671-687.

Cordes, P.J., Zagubione ojcostwo (trans. J. Kożbiał) (Pelplin: Bernardinum 2005).

Eldredge, J., Dzikie serce. Tęsknoty męskiej duszy (trans. J. Grzegorczyk) (Poznań: W drodze 2003).

de Fiores, S., La "Nuova” Spiritualità (Roma: Studium 1995).

Franklin, C.W., The Changing Definition of Masculinity (New York: Plenum 1984).

Górski, K., „Teologia mistyczna Jakuba z Paradyża, Roczniki Filozoficzne 27/1 (1979) 217-229. 
de Grandis, R. - Schubert, L., Uzdrowienie międzypokoleniowe (trans. B. Włodarczyk) (Łódź: Ośrodek Odnowy w Duchu Świętym 2012).

Grün, A., Walczyć i kochać. Mężczyźni w poszukiwaniu własnej tożsamości (trans. B.M. Kamińska) (Częstochowa: Święty Paweł 2005).

Guerra, A., “Teologia espiritual, una ciencia no identificada," Revista di Espiritualidad 39 (1980) 335-414.

Guggenbühl, A., Men, Power, and Myths: The Quest for Male Identity (New York: Continuum 1997).

Haddad T. (ed.), Men and Masculinities: A Critical Anthology (Toronto: Canadian Scholar's Press 1993).

Hart, A.D., Męska depresja (trans. A. Gomola) (Poznań: W drodze 2004).

Hicks, R., The Quest of Self-Understanding: Uneasy Manhood (Nashville, TN: Oliver-Nelson 1991).

Holt, B.P., "Duchowość dwudziestego wieku," Duchowość chrześcijańska (ed. G. Mursell; trans. B. Śliwińska et al.) (Częstochowa: Edycja Świętego Pawła 2004) 305-365.

Horrocks, R., Masculinity in Crisis: Myths, Fantasies, and Realities (New York: St. Martin's Press 1994).

John Paul II, "Post-Synodal Apostolic Exhortation Pastores Dabo Vobis," Acta Apostolicae Sedis 84 (1992) 658-804.

John Paul II, "Encyclical Redemptoris Mater," Acta Apostolicae Sedis 79 (1987) 361-433.

John Paul II, "Apostolic Letter Novo Millennio Ineunte," Acta Apostolicae Sedis 93 (2001) 266-309.

Jan Paweł II, Mężczyzna i niewiasta stworzył ich. II. Chrystus odwołuje się do „serca” (Lublin: Redakcja Wydawnictw KUL 1987).

Jastrzębski, A., Homo Theomorphicus et Theophoricus, A Receptive-Responsive Theory of Spirituality (Leuven - Paris - Bristol: Peeters 2019).

Kapuściński R., “Spotkanie z Innym jako wyzwanie XXI,” R. Kapuściński Ten inny (Kraków: Znak 2006), 63-76.

Kilpatrick, W.K., Psychologiczne uwiedzenie (trans. J. Lewandowski) (Poznań: W drodze 1997).

Kobyliński, A., "Etyczne aspekty współczesnej pentekostalizacji chrześcijaństwa," Studia Philosophiae Christianae 50/3 (2014) 93-130.

Lubowicki, K., "Posłowie," Kongregacja Nauki Wiary, Instrukcja „Ardens felicitatis desiderium” na temat modlitwy o uzdrowienie (Wrocław: Tum 2003) 30-54.

Matanić, A.G., La spiritualità come scienza. Introduzione metodologica allo studio della vita spirituale cristiana (Cinisello Balsamo: Paoline 1990).

McAll, K., Healing the Family Tree (London: Shelton Press 1982).

Meetschen, S., Cyfrowa duchowość (trans. A. Meetschen) (Warszawa: Wydawnictwo Sióstr Loretanek 2013).

Mosse, G.L., The Image of Man: The Creation of Modern Masculinity (Oxford: Oxford University Press 1996).

Niewiadomska, I., "Postawa," Leksykon duchowości katolickiej (ed. M. Chmielewski) (Lublin Kraków: Wydawnictwo M 2002) 684.

Ogorzałek, G., Duchowość spotkania w życiu i twórczości Henriego Nouwena (Kraków: Salwator 2016). 
Pacot, S., Droga wewnętrznego uzdrowienia (trans. M. Jarosiewicz) (Poznań: W drodze 2002).

Paszkowska, T., Formacja eklezjalna. Permanentny proces odnowy osobowej (Kraków: Alleluja 2019).

Peterson, E.H., Christ Plays in Ten Thousand Places: A Conversation in Spiritual Theology (London: Hodder \& Stoughton 2005).

Piasecki, P., Medytacja chrześcijańska. Antropologiczno-teologiczne podstawy w perspektywie duchowości azjatyckiej (Poznań: UAM. Wydział Teologiczny 2008).

Pleck J.H., The Myth of Masculinity (Englewood Cliffs, NJ: Prentice-Hall 1974).

Rotundo, E.A., American Manhood: Transformations in Masculinity from the Revolution to the Modern Era (New York: BasicBooks 1997).

Rohr, R., "Masculine Spirituality," The New Dictionary of Catholic Spirituality (ed. M. Downey) (Collegeville, MN: Liturgical Press 1993) 645-647.

Ryan, T., Four Steps to Spiritual Freedom (New York - Mahwah: Paulist Press 2003).

Rybicki, A., "Christian Spiritual Experience as a Model of a Culture of Dialogue," Journal for Perspectives of Economic Political and Social Integration 22/1-2 (2016) 85-94.

Siemieniewski, A., Ochrzczeni w jednym Duchu. Perspektywy integracji mistycyzmu pentekostalnego z duchowością katolicka (Wrocław: Papieski Wydział Teologiczny 2002).

Sowers, J., Droga wojownika. W poszukiwaniu męskiego serca (trans. M. Piątek) (Kraków: eSPE 2014).

Stearns, P.N., Be a Man! Males in Modern Society (New York: Holmes \& Meier 1990).

Stępień, T., "Przedmowa," Pseudo-Dionizy Areopagita, Pisma teologiczne, wyd. 2 (Kraków: Znak 2005), 7-15.

Thompson, H., Journey Toward Wholeness. A Jungian Model of Adult Spiritual Growth, (New York - Ramsey, NJ: Paulist Press 1982).

Tornielli, A. - Gaeta, S., A.D. 2012. Czy nadchodzi koniec świata? (trans. A. Ferens-Kręciszewska) (Kraków: Znak 2012).

Tułowiecki, D., "Kultura spotkania jako odpowiedź papieża Franciszka na globalny problem społeczny braku bezpieczeństwa," Studia Teologiczne 34 (2016) 375-400.

Weigel, G., Katolicyzm ewangeliczny (trans. K. Gomola - A. Gomola) (Kraków: Wydawnictwo M 2014). 